\title{
Liquefaction susceptibility mapping using geotechnical laboratory tests
}

\author{
${ }^{1 *}$ M. El May; ${ }^{2}$ J. Kacem; ${ }^{1}$ M. Dlala \\ ${ }^{1}$ Paleoenvironment, Geomaterial and Sismic Risk Laboratory, Departement of Geology, Faculty of Sciences, University \\ Tunis El Manar, Tunisia \\ ${ }^{2}$ Departement of Earth Sciences, Faculty of Sciences of Bizerte, Tunisia
}

Received 22 May 2008; revised 30 October 2008; accepted 25 November 2008; available online 1 March 2009

\begin{abstract}
The soil liquefaction potential has been evaluated for the Ariana Region because of its important socioeconomic interest and its location. Liquefaction susceptibility mapping is carried out using a decisional flow chart for evaluation of earthquake-induced effects, based on available data such as paleoliquefaction, geological, groundwater depth, seismotectonic, sedimentary features and geotechnical parameters in particular laboratory testing like grain size analyses and state parameters. Survey results showed that some of these localities are considered as possible sites to soil liquefaction. Indeed, Quaternary alluvium deposits, paleo beaches and recent deposits that edge the lake and the sebka constitute the most susceptible locations to liquefaction. In the east and the west sides of the studied zone, Quaternary deposits are less susceptible to the liquefaction due to the groundwater level deepening and to the relatively old age of the deposits. Elsewhere sedimentary formations are classified as non-liquefiable as they are heavily compacted and old.
\end{abstract}

Keywords: Soil liquefaction, site effects, regional seismic hazard, local seismic hazard

\section{INTRODUCTION}

In Tunis, regional seismic hazard survey has been advanced by Kacem (2004). It shows that Tunis area, including Offshore Gulf presents a strong regional seismic hazard, in view of the fact that the peak horizontal acceleration at ground surface in Ariana area reached the value of $0.2 \mathrm{~g}$ for a return period of 475 years. It has become a necessity to develop a local hazard map as the area is very populated and economically very important. Ariana area is located in northern east of Tunis city. Due to the extensive development in the twentieth century, this region and its vicinities have become one of the largest urban areas in the north (Fig. 1). Ariana area is a simple geological structure, it is formed by a central basin called "Soukra alluvial plain" filled by the quaternary deposits and surrounded by hills such as Sidi bou Saïd and Gammarth hills to the East, J. Nahli anticline to the West and southTunis- hills to the south. During geological history of this area, sedimentary events have influenced deposits characteristics, as well as morphology of the site. In fact, the isolation of Ariana Sebkha through a coastal cord was at the origin of Soukra paleo-dunes and the existence of sandy deposits in the west part of

$\triangle$ *Corresponding Author Email: elmaymoufida@yahoo.fr Tel./Fax: +21697674 190
Gammarth. Sedimentation of thick detritus materials in Tunis lagoon shore evokes an old estuary (Pimienta, 1959). In addition, some previous works showed the existence, between Belvedere hills and Tunis Lake, of a thick river channel deposits that has for origin the passageway through Tunis city of a big valley, called Medjerda valley (Pimienta, 1959). It was at the origin of the alternation between clayey, coarse and fine sandy deposits.

Sediment properties (lithology, age of deposit, grain size and shape and deposit compactness) and hydrogeological conditions (groundwater level) make the site favorable for seismic wave amplification. Consequently, this makes the soil prone to liquefaction upon seismic shaking (Stephen et al., 2004).

In this case, where coarse silty, sandy soil and shallow groundwater level are present, long duration of strong earthquake tends to increase soil liquefaction potential (Ozdemir and Ince, 2004). That is why it must be evaluated for better risk and mitigation measures. The use of geotechnical data in particular laboratory testing like grain size analyses and state parameters Sa, Ar, Ex given by (PS 92) rules make possible the apply of the decisional chart for evaluation of earthquake-induced liquefaction susceptibility (PS 92). 
Geological data supported by geotechnical criteria appears to be a valuable contribution to liquefaction hazard map in Ariana Region. The aim of this study is to provide a preliminary zonation based on soil liquefaction potential using the following criteria: deposit properties $(\mathrm{N})$, historical data $(\mathrm{H})$, type and deposit age $\left(\mathrm{G}_{1}\right)$, deposit age and groundwater level $\mathrm{G}_{2}$. This is an effective mean to delineate areas prone to seismic hazards (Aaron et al., 2001) based on surficial geologic mapping considered as the most important factor controlling liquefaction susceptibility (Youd, 1991). Thus, mapping surface and near-surface geology, liquefaction susceptibility can be qualitatively assessed (Youd and Perkins, 1978).

\section{MATERIALS AND METHODS}

Regional geology and seismotectonic structures of the study area and its surrounds are investigated. Groundwater level map, liquefaction susceptibility map and seismic map are established. The details used in the preparation of these map are presented later in the paper.

\section{Structural context and seismic opportunity}

To study soil liquefaction potential, adopted method requires, firstly, the seismic characteristics of the region because intensity and duration of earthquake are the primary factor controlling the liquefaction of saturated cohesionless soil in ground level (Finn, 2001).

In Tunisia, compressive tectonic has started since upper Miocene and continues until present with a NWSE shortening direction (Philip, 1987; Dlala, 1995). Compressive tectonics was at the origin of important happened earthquakes. Epicenter distribution map for the period between 856 until the year 2000 show that Tunis area is characterized by a weak magnitude of earthquakes (1.4 to 3.8) (Fig. 2). Earthquake of magnitude $M \geqslant 4$ are localized especially in Tunis, Ariana, Chaouat, Sidi Thabet and Utique region. Strongest earthquakes were of 4.3 on Richter scale recorded at Jebel Ressas and 5.1 on Richter scale at Jedaida region during the Chouat and Sidi Thabet 1970 earthquake. These are the nearest epicenter to the study area and the more felt by the population. They even induced soil liquefaction (Fig. 4). In spite of the

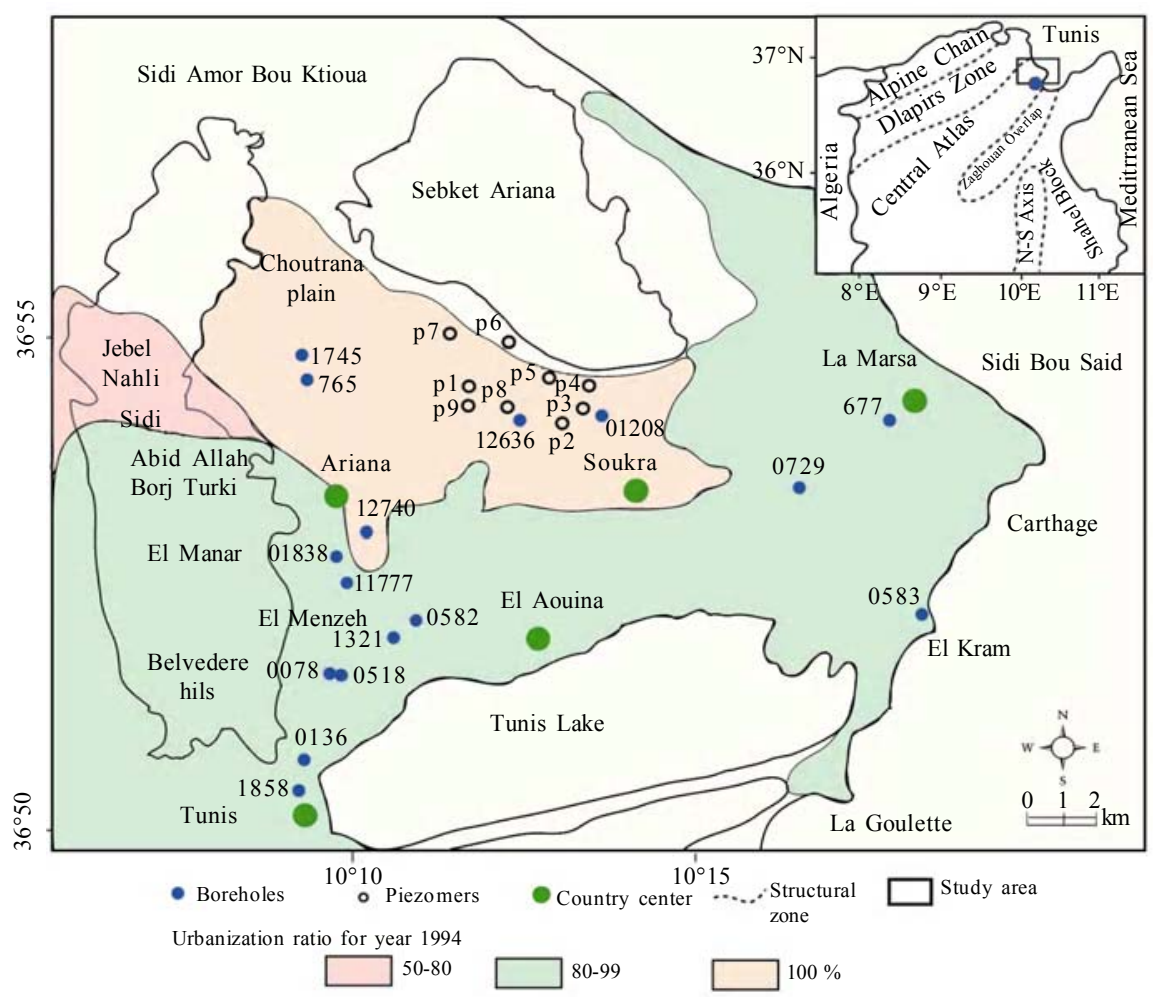

Fig. 1: Localisation map of the study area and borehole positions 
Int. J. Environ. Sci. Tech., 6 (2), 299-308, Spring 2009

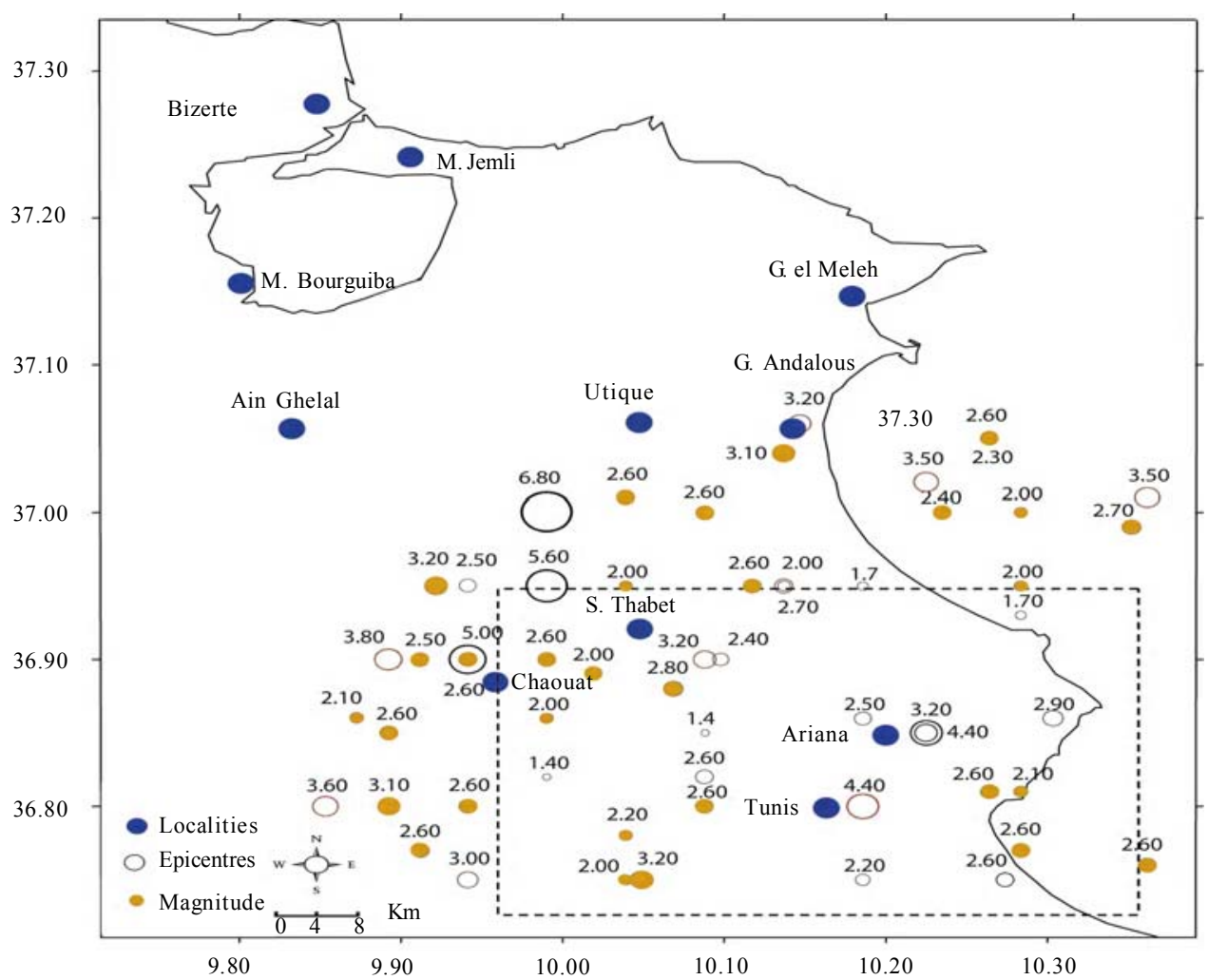

Fig. 2: Seismic map of the study area and its surrounding from 856 to 2003

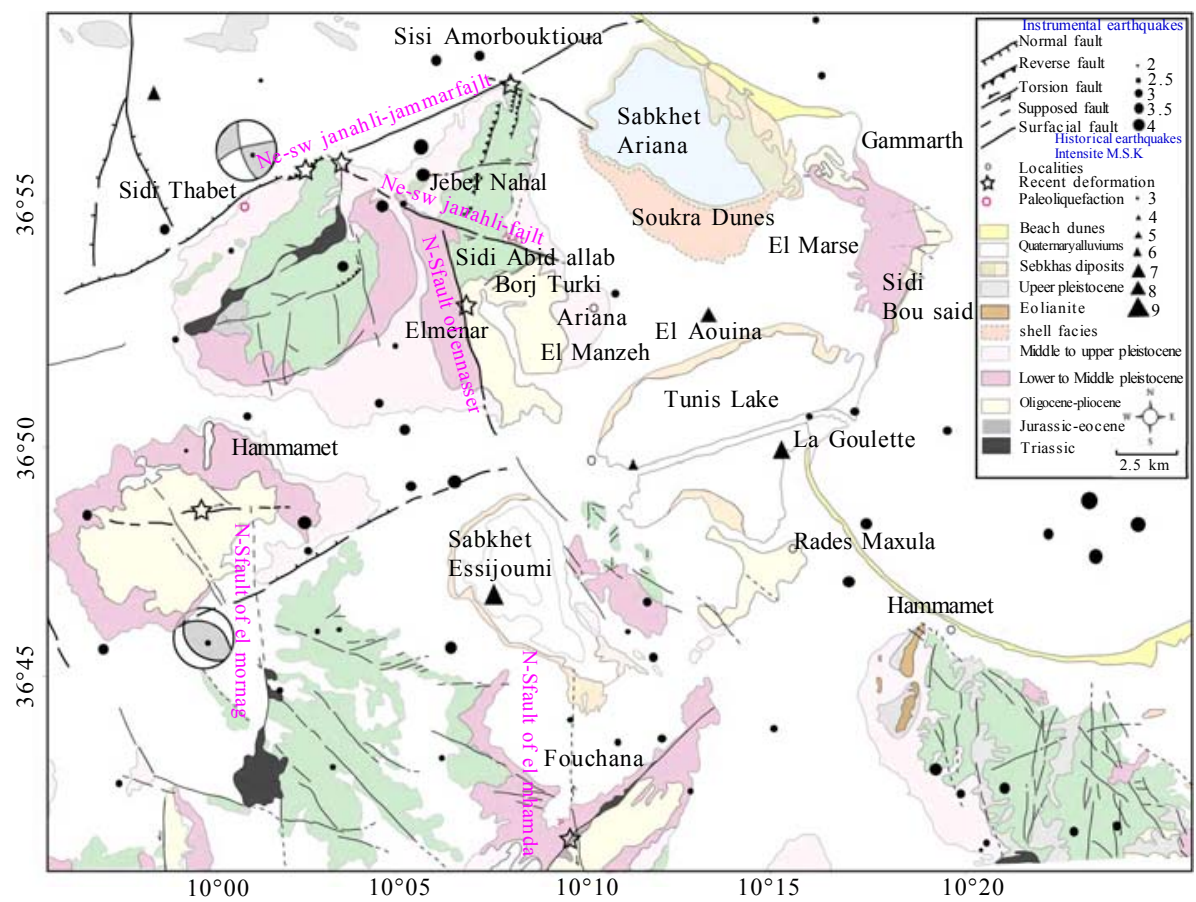

Fig. 3: Extract of sismotectonic map of the study area (Dlala and Kacem, 2007) 


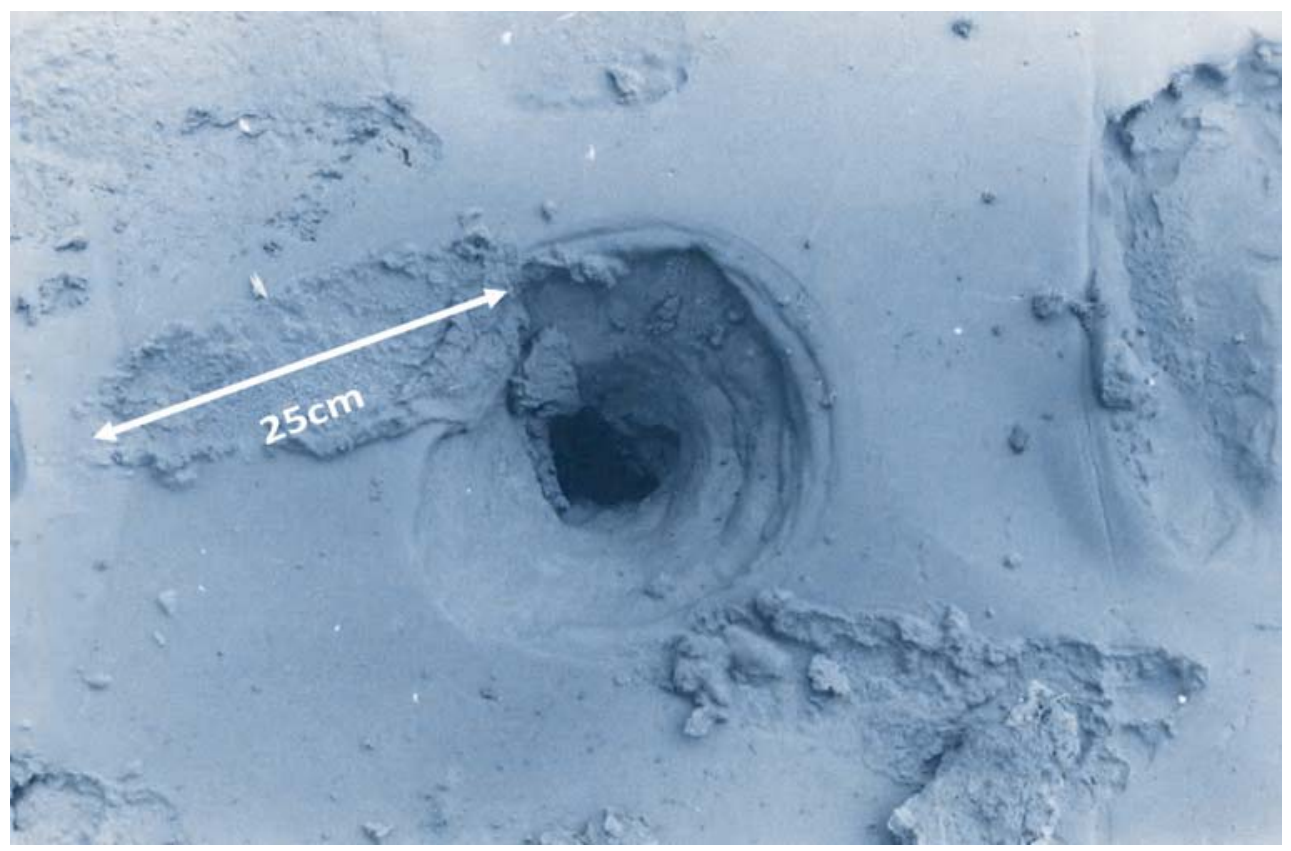

Fig. 4: Sand craters observed in Sidi Thabet due to the earthquake of 12/12/1970

dominance of weak magnitude seismicity, recent deformation indices have been observed and studied. These indices are associated to main active faults such as NW-SE Jebel Nahli fault: shifts to senestral strike-slip fault at the anticline of Jebel Nahli. It affects the chalky encrustations, the upper Pleistocene aged red silts and the shallow encrustations and powdery deposits. The normal faults network with NE-SW direction at Jebel Nahli-Jebel Amar, affect the most recent quaternary deposits. El Mnihla Quaternary aged deposits are separated from El Menzeh and El Manar Pliocene marly combes by a N-S morphological ramp. In this locality, a major fault appears on several $\mathrm{km}$ affecting the most recent quaternary deposits: It is a senestral strike-slip fault where slip indices have been observed. In the Southbound survey sector, NS El M'hamdia fault affects the red silts and the most recent chalky encrustations (Fig. 3).

Recent deformation signs confirm the importance of the actual seismic activity that in spite of its weak magnitude affects recent and most shallow deposits. This confirms the particularity of the Tunisian seismicity showed by Dlala et al. (1994). They prove that Tunisia area is characterized by very superficial sismicity focus.

\section{Historical data}

The knowledge of historically submissive zones to the soil liquefaction or Paleoliquefaction permits a first localization of liquefiable zones (Ishihara and Yasuda, 1991; Pecker, 1984). However, the absence of recorded historical event cannot reject directly liquefaction risk (BRGM-ARN/RGC, 2002). Bibliographic researches concerning historical seismic events lived in Tunisia did not give results signaling the existence of soil liquefaction. Except the 12/12/1970 earthquake that shook the region of Sidi Thabet-Chaouat, situated in the north west of this survey sector $(9 \mathrm{~km}$ far from Ariana Region). The earthquake is with magnitude of 5.1 on Richter scale and has generated Chaouat soil liquefaction. These events have been photographed and archived by the National Institute of Meteorology (Fig. 4). The very few records of this kind of phenomena in Tunisia do not mean that it has never occurred in the past, but could be due to the lack of information or to absence of strong earthquakes that produce liquefaction.

\section{Groundwater table map}

The position of the groundwater table is an important parameter for liquefaction analysis (Rix and Romero-Hudock, 2006). In this study area, sedimentary 
events added to morphologic conditions, permitted the creation of superposed groundwater tables occupying a large part of the studied zone like Quaternary alluvium aquifer and Soukra dune aquifer. Groundwater depth map was prepared from a survey of groundwater level of 12 boreholes and 9 piezometer. Two principal superposed aquifers have been identified. They are implicated in all possible earthquakes: The Soukra dunes aquifer and the Quaternary deposit aquifer that cover the entire middle part of the studied zone. Recharge is carried out through rainfall infiltration, Quaternary alluvium reservoirs and by Mio-Pliocene aquifer. The static level is generally superficial; it does not exceed the depth of $10 \mathrm{~m}$, it is less than $2 \mathrm{~m}$ for the Soukra dunes aquifer, around $3 \mathrm{~m}$ on the middle of the alluvium plain and reach $5 \mathrm{~m}$ at J. Nahli underside (Fig. 5).

\section{Surface geology data}

In Ariana Region, sedimentary deposits are from Cretaceous to present, with the dominance of Neogene deposits that occupies Soukra alluvial plain and the western part of Sidi Bou Saïd hills. Cretaceous outcrops constitute the oldest deposits composed of alternations of marl and limestone. They are essentially localized in Jebel Nahli anticline (Fig. 3). Eocene deposits crop out at south of the capital Tunis composed of marls and limestones. Sidi Bou Saïd hills are essentially composed of oligo-aquitaniens deposits with sandstone, clay, siltstone and sandy features. Mio-Pliocene outcrops are localized at the west part of Ariana and in El Menzeh and El Manar hills as clayey-gritty deposits. LowerVillafranchian outcrops are observable at Borj Turki to the NW of Ariana area and in Sidi Abid Allah locality. They are a detrial, silty and conglomeratic deposits. They have as origin the dismantle products of adjoining studied sector hills. Middle and Upper-quaternary outcrops are localized in the underside of hills. Somewhere else studied area is occupied by slope deposits, old soils, quaternary aged alluviums and actual coast dunes (Ansal et al., 1994; Hamada and Aydan, 1992; Rathje et al., 2004). These deposits occupy the central part of the studied area and make the essential object of this survey. It has been observed that during past earthquakes much liquefaction has occured in valleys, plains, lakes and coastral regions (Sonmez and Ulusay, 2008; Soysal et al., 1981; Papathanassiou et al., 2005; Ulusay et al., 2000; Yuan et al., 2003). Mainly, in the case of a sallow groundwater table and young grained deposits; in these populated areas, loss of property may occur in case of earthquakes due to the soil liquefaction (Ozdemir and Ince, 2004).

\section{RESULTS AND DISCUSSION}

Liquefaction susceptibily based on type and age of deposit criteria

Estimated susceptibility to liquefaction of deposits, during strong seismic shaking advanced by Youd and Perkins (1978) prove that the liquefiable soils are particularly the quaternary deposits in general younger than 1.650000 years. The use of this classification shows formations that can be liquefied in Fig. 6.

\section{Liquefaction susceptibily based on age and groundwater table depth criteria}

Liquefaction susceptibility of deposits according to criteria deposit age and groundwater level map. Qualitatively, assessement of liquefaction susceptibility (Fig. 6) proves that sebka and lake boundaries deposits and alluviums occupying the plain between Sebkhet Ariana and the Tunis Lake are recent Holocene. Groundwater level is less than $3 \mathrm{~m}$. In these localities, liquefaction susceptibility is estimated as high to very high. Soukra area is occupied by paleao-beaches that crop out in the south of Sabkhet Ariana. They are Upper Holocene in age ( $<10000$ years). This Upper Holocene granular sediment would be with a very high liquefaction susceptibility. They generally meet the liquefaction criteria such as age, texture, degree of saturation and depositional environment. Jebel Nahli underside and Ariana city consist of old quaternary formations where groundwater level generally decreases. The Upper Pleistocene deposits are of moderate liquefaction susceptibility whereas the older formations (MiddlePleistocene to Lower-Pleistocene) are of very weak liquefaction susceptibility. According to Youd and Perkins (1978), classification deposits of J. Nahli from the locality of Sidi Amor Bou Khtiouas to Northern hills of the capital are liquefaction immune as they are of Cretaceous age. Pliocene deposits situated to the East of Sebkhet Ariana and Eocene deposits localized to the South of Tunis city and deposits located in the extreme East of the study area of OligoMiocene to Miocene do not meet the liquefaction susceptibility criteria. Upper Oligocene aged deposits are also not liquefiable. All these formations are considered as non liquefiable. 


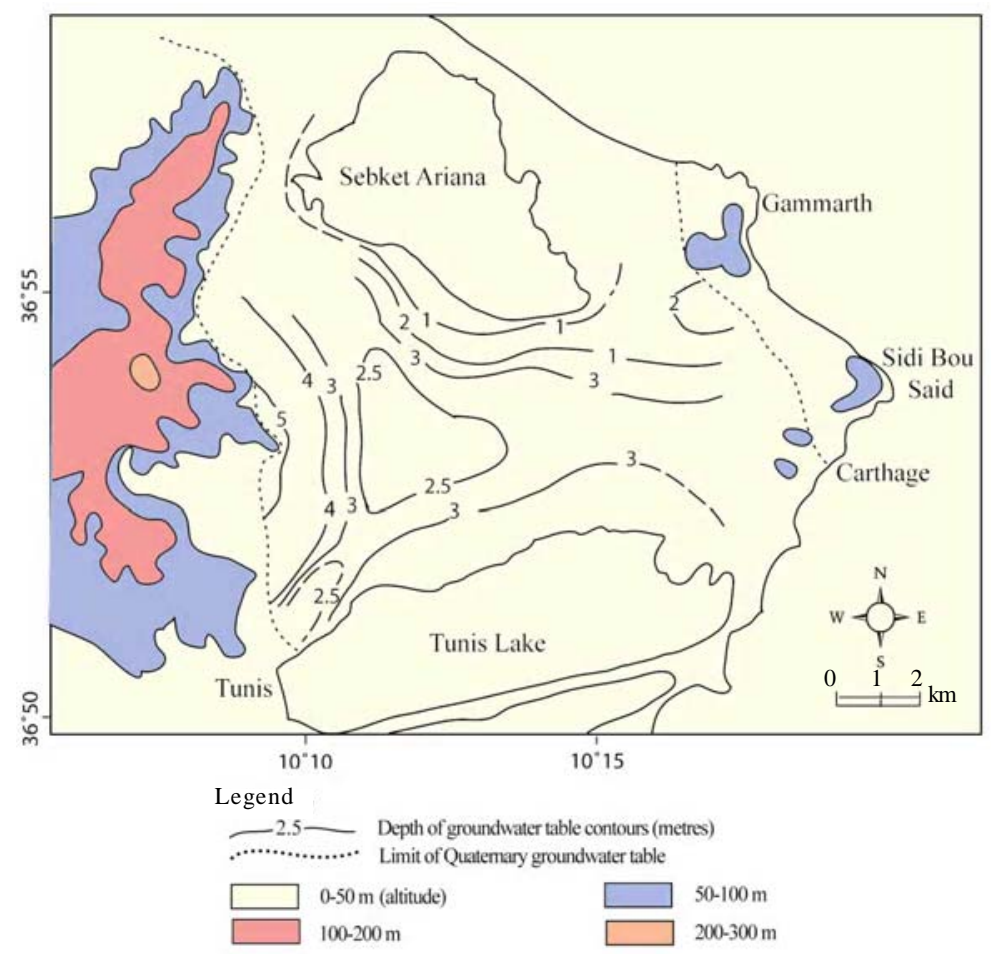

Fig. 5: Map of groundwater table depth

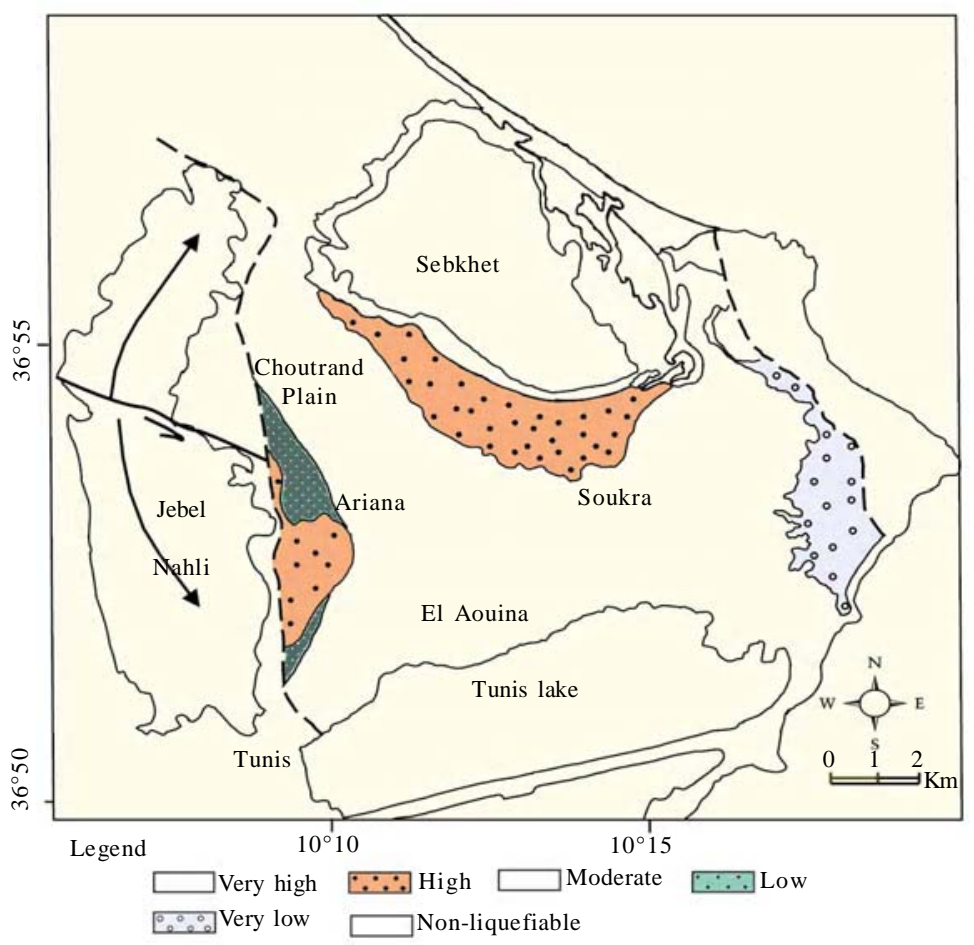

Fig. 6: Liquefaction susceptibility map based on critaria: Deposit age and groundwater table depth 
Int. J. Environ. Sci. Tech., 6 (2), 299-308, Spring 2009

Table 1: Identification criteria of liquefiable soils (PS 92)

\begin{tabular}{|c|c|c|}
\hline Vasards sands and siltses & Clayey soils & Exclusive criteria \\
\hline $\begin{array}{l}\text { Sa1: Under water table either degree of } \\
\text { saturation Sr } 100 \% \\
\text { Sa2: Uniform granulomety: } \\
\mathrm{Cu}=\mathrm{D} 60 \text { / D10 } 15 \\
\mathrm{Sa} 3: 0.05 \mathrm{~mm}<\mathrm{D} 50<1.5 \mathrm{~mm} \\
\text { Sa4: Efficient constraint according to the } \\
\text { seismic zones: } \\
\text { I zone: } \sigma^{\prime} \quad<200 \mathrm{KPas} \\
\text { II zone: } \sigma^{\prime} \quad<250 \mathrm{KPas} \\
\text { III zone: } \sigma^{\prime} \quad<300 \mathrm{KPas}\end{array}$ & $\begin{array}{l}\text { Ar1: D15 }>5 \mu \mathrm{m} \\
\text { Ar2: Liquidity limit lower to } 35 \% \mathrm{LW}<35 \% \\
\text { Ar3: Material near of the liquidity limit of W } 0.9>\mathrm{LW} \\
\text { Ar4: Representatif point on the malleability diagram is } \\
\text { situated over of the line "A" }\end{array}$ & $\begin{array}{l}\text { A - Coarse soils } \\
\text {-Ex1: D10 }>2 \mathrm{~mm} \\
\text { B- Extremely simultaneous fines soils } \\
\text { - Ex11: } \mathrm{D}_{70}<74 \mu \mathrm{m} \\
\text { - Ex22: Ip }>10 \%\end{array}$ \\
\hline
\end{tabular}

Table 2: Geotechnical data use to the determination of (Ar and Sa) parameters

\begin{tabular}{|c|c|c|c|c|c|c|c|c|}
\hline \multirow[b]{2}{*}{ Borehole nember } & \multicolumn{4}{|c|}{ Sandy sol Sa } & \multicolumn{4}{|c|}{ Clayey sol $\mathrm{Ar}$} \\
\hline & $\mathrm{Cu}$ & $\mathrm{D}_{50}$ & $\sigma_{\mathrm{v}}^{\prime}(\mathrm{KPa})$ & Z & $\mathrm{W}_{\mathrm{L}}$ & $\mathrm{I}_{\mathrm{P}}$ & W & Z \\
\hline 0078 & 6.25 & 0.3 & 126 & 6.6 & 27 & 13 & 12 & 2.5 \\
\hline 0518 & 6.25 & 0.2 & 84 & 4 & 35 & 20 & 22 & 7 \\
\hline 0582 & 3 & 0.1 & 52.2 & 2.5 & 30 & 15 & 24 & 7.5 \\
\hline 0729 & - & - & - & - & 3 & 20 & 21 & 6 \\
\hline 12636 & 2.2 & 0.25 & 189 & 9 & - & - & - & - \\
\hline 01838 & 1.25 & 0.09 & 105 & 5 & 27 & 13 & 15 & 2.5 \\
\hline 677 & - & - & - & - & 40 & 28 & 22 & 6 \\
\hline 1321 & 3 & 0.1 & 63 & 3 & 41 & 23 & 25 & 5 \\
\hline 01208 & 1.5 & 0.12 & 58.8 & 2.8 & 54 & 32 & 36 & 11 \\
\hline 0583 & 2.4 & 0.12 & 63 & 3 & - & - & - & - \\
\hline 1745 & - & - & - & - & 58 & 35 & 24 & 2 \\
\hline 765 & - & - & - & - & 31 & 16 & 17 & 2 \\
\hline$P_{1}$ & 1.6 & 0.2 & 21 & 1 & - & - & - & - \\
\hline $\mathrm{P}_{2}$ & 2.2 & 0.25 & 21 & 1 & - & - & - & - \\
\hline $\mathrm{P}_{3}$ & 2.1 & 0.25 & 21 & 1 & - & - & - & - \\
\hline $\mathrm{P}_{4}$ & 2 & 0.2 & 21 & 1 & - & - & - & - \\
\hline $\mathrm{P}_{5}$ & 1.8 & 0.15 & 21 & 1 & - & - & - & - \\
\hline $\mathrm{P}_{6}$ & 1.5 & 0.2 & 21 & 1 & - & - & - & - \\
\hline $\mathrm{P}_{7}$ & 1.8 & 0.18 & 21 & 1 & - & - & - & - \\
\hline $\mathrm{P}_{8}$ & 3.5 & 0.18 & 21 & 1 & - & - & - & - \\
\hline $\mathrm{P}_{9}$ & 2.1 & 0.11 & 21 & 1 & & & & \\
\hline
\end{tabular}

\section{Geotechnical contribution}

Using the geotechnical data, it will be produced a more refined map than that based on the geomorphological conditions alone (Kramer, 1996). It follows the recommendations published as methodological guide for the realization of seismic microzonation survey-AFPS 1993, level B.

In this work, criteria were adopted for potentially liquefiable soils identification defined by paraseismic rules construction PS92 and French NF P 06-013 norms that are summarized in Table 1

Determination of criteria "Ar" and "Sa" (Table 1) permits to apply the decisional diagram or flow-chart advanced by BRGM-ARN/RGC (2002) to establish soil liquefaction susceptibility map. The geotechnical index from which the latter parameters ( $\mathrm{Ar}$ and $\mathrm{Sa}$ ) were calculated are summarized in Table 2.
Results of the apply of the decisional diagram for the assessed of liquefaction susceptibility in the study area are recapitulated in Table 3.

\section{Liquefaction susceptibility mapping of ariana area}

Geological data supported by geotechnical criteria appears to be a valuable contribution to liquefaction hazard map in Ariana Region. Survey results showed that in the region called Soukra dune which consists of a Holocene dune, situated to the South of Sebkhet Ariana, geotechnical test results, obtained from 9 piezometer and 2 boreholes (numbers 12636 and 01208), show that this zone presents high to very high liquefaction susceptibility. It is due to the gathering of three conditions which are age of the deposit, hydrogeologic and lithologic conditions. According to the the existence of the same parameters in the east 
Liquefaction susceptibility mapping

Table 3: Earthquake-induced liquefaction susceptibility assessed using the decision flow chart from BRGM-ARN/RGC

\begin{tabular}{rrrlllcl}
\hline $\begin{array}{c}\text { Borehole } \\
\text { No. }\end{array}$ & N Criteria & H Criteri & $\mathrm{G}_{1}$ Criteria & $\mathrm{G}_{2}$ Criteria & Ex Criteria & Sa or Ar Criteria & $\begin{array}{c}\text { Liquefaction } \\
\text { susceptibility }\end{array}$ \\
\hline 0087 & Yes & No & Low & Moderate & No & $\mathrm{N}=3$ & Low to moderate \\
0518 & Yes & No & High & High to very high & No & $\mathrm{N}=4$ & High to very high \\
0582 & Yes & No & High & High to very high & No & $\mathrm{N}=4$ & High to very high \\
0729 & Yes & No & High & High to very high & No & $\mathrm{N}=3$ & High to very high \\
01838 & Yes & No & Low & Low & No & $\mathrm{N}=4$ & Low to moderate \\
1321 & Yes & No & High & High to very high & No & $\mathrm{N}=4$ & High to very high \\
01208 & Yes & No & Moderate & Moderate & No & $\mathrm{N}=4$ & High to very high \\
12636 & Yes & No & Moderate & High & No & $\mathrm{N}=4$ & High to very high \\
0583 & Yes & No & Very low & Low & No & $\mathrm{N}=3$ & Low or nil \\
1745 & Yes & No & High & Very low & No & $\mathrm{N}=1$ & Low or nil \\
765 & Yes & No & High & Very low & No & $\mathrm{N}=2$ & Low or nil \\
677 & Yes & No & Low & Low & No & $\mathrm{N}=1$ & Low or nil \\
$\mathrm{P}_{1}$ & Yes & No & Moderate & High & No & $\mathrm{N}=4$ & High to very high \\
$\mathrm{P}_{2}$ & Yes & No & Moderate & High & No & $\mathrm{N}=4$ & High to very high \\
$\mathrm{P}_{3}$ & Yes & No & Moderate & High & No & $\mathrm{N}=4$ & High to very high \\
$\mathrm{P}_{4}$ & Yes & No & Moderate & High & No & $\mathrm{N}=4$ & High to very high \\
$\mathrm{P}_{5}$ & Yes & No & Moderate & High & No & $\mathrm{N}=4$ & High to very high \\
$\mathrm{P}_{6}$ & Yes & No & Moderate & High & No & $\mathrm{N}=4$ & High to very high \\
$\mathrm{P}_{7}$ & Yes & No & Moderate & High & No & $\mathrm{N}=4$ & High to very high \\
$\mathrm{P}_{8}$ & Yes & No & Moderate & High & No & $\mathrm{N}=4$ & High to very high \\
$\mathrm{P}_{9}$ & Yes & No & Moderate & High & & & \\
\hline
\end{tabular}

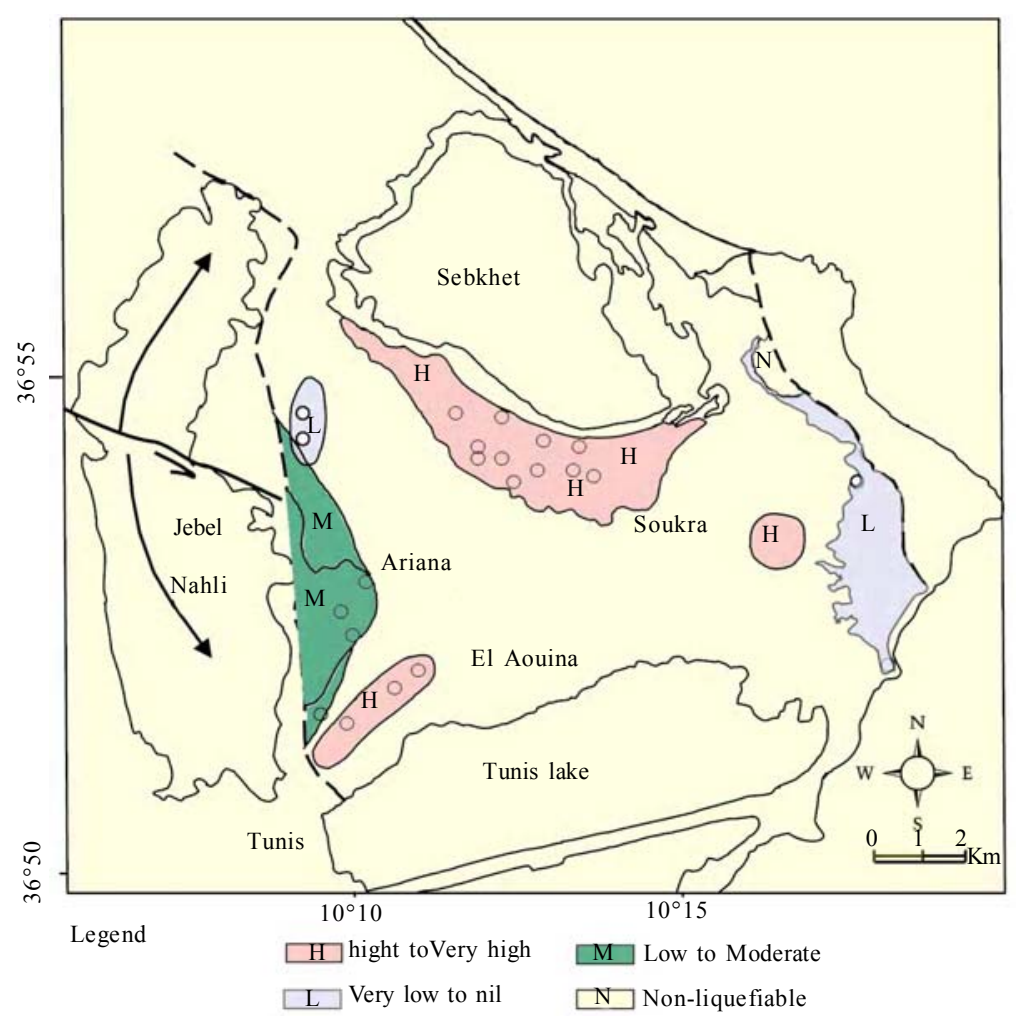

Fig. 7: Liquefaction susceptibility map of Ariana Region and its vicinity 
and in the west supposed that all the zone called "Soukra dunes" is of a high to a very high liquefaction susceptibility (Fig. 7).

Ariana Region, situated to the J. Nahli anticline underside, is dominated by Middle to UpperPleistocene age formations to the west and by recent quaternary formations to the north and the south part. Ariana region, according to samples from boreholes numbers $11777,12740,01838,0087$, is of weak to moderate liquefaction susceptibility in spite of the recent age of its deposits. In region located between Belvedere hills and Tunis Lake, geotechnical data from boreholes numbers $0582,1321,0518$ realized in this zone show that liquefaction susceptibility is high to very high. Furthermore, the deposit is very recent and the groundwater level is about $3 \mathrm{~m}$ deep. In south Marsa Region Lower to Middle Pleistocene, deposits are situated to the west part of Sidi Bou Saïd-Gammarth hills. It includes two boreholes, numbers (677and 0583) situated in extreme part of the study area. In these localities, survey results show that liquefaction susceptibility is low or nil. Deposit age and the absence of quaternary aquifer in this region permit to say that the results given by the boreholes can be applied on all this formation. The central part situated between Sebkhet Ariana to the north and Tunis Lake in the south is filled in by recent Quaternary deposits. The groundwater level is generally at $3 \mathrm{~m}$ from the ground surface. It is considered that according to the applied model, as high to very high liquefaction susceptibility. This was confirmed by the borehole of Sidi Daoued (0729). In areas occupied by sebka and lake borders deposits, in spite of the absence of geotechnical data, this zone is considered as very susceptible to liquefaction, because it is constituted of very recent, badly compacted and saturated deposits. The degree of saturation attains $100 \%$.

\section{CONCLUSION}

Tunis Region is characterized by the dominance of recent sedimentary formations, heterogeneous deposits, little constrained and sandy sedimentation. These sedimentary features define shallow aquifers among which are the Quaternary alluvium aquifer and Soukra paleo-dunes aquifer. The seismotectonic context characterized by a regional seismicity of relatively high ground acceleration (superior to $0.2 \mathrm{~g}$ ) constitute a favorable field for the manifestation of induced effects or site effects in case of an earthquake.
Soil liquefaction has been already signaled in the Sidi Thabet zone during the 1970 earthquake with a magnitude of 5.1 Richter.

In the region of Ariana, qualitatively assessment of liquefaction potential supported by geotechnical data gave important indications in localities where underground water level is shallow, the age of the sedimentary deposits is recent and sediments satisfy the already mentioned geotechnical criteria. This study confirms that soil is susceptible to liquefaction under $0.2 \mathrm{~g}$ earthquake acceleration. For these reasons, in Ariana city and other similar places, soil may liquefy significantly in the case of a possible earthquake. Thus, the damage may become higher in those regions. This study indicated that it is necessary to take preventative measures in these regions to save human lives and to prevent damage. Site-specific geotechnical investigations should be performed in areas of high or moderate susceptibility to assess risk to the existing facilities and to evaluate and mitigate liquefaction hazards prior to future development, especially when the concerned area is of an important socioeconomic interest.

\section{ACKNOWLEDGEMENTS}

The authors would like to thank Mrs. Aouicha badday, a Deputy Director in Test Center and Construction Techniques for her orientation and help to give as data.

\section{REFERENCES}

Aaron, T. B.; Roy, B.; Van, A.; Jason, H. B., (2001). Liquefactionsusceptibility mapping in thecity of memphis and shelby country. Tennessee. Eng. Geo., 62 (1), 207-222 (16 pages).

AFPS, (1993). Guide méthodologique pour la réalisation d'étude de microzonage sismique. Saint-Rémy-lès-Chevreuse.

Ansal, A. M.; Lav, A. M.; I yisan, R.; Ve Erken, A., (1994). Effects ofgeotechnical factors in March 13,1992 Erzincan Earthquake. $13^{\text {th. }}$ international conference on soil mechanics and foundation engineering, New Delhi, 49-54 (6 pages).

BRGM-ARN/RGC, (2002). Aide mémoire géotechnique pour les études de risque dans le domaine de la liquéfaction des sols. Aide mémoire géotechnique pour les études de risque dans le domaine de la liquéfaction des sols, 43 .

Dlala, M.; Rebai, S.; Philip, H., (1994). Approche sismotectonique des caractères de la sismicité en Tunisie. C. R. Acad. Sci. Paris. t. 319 (5), 573-579 (7 pages).

Dlala, M., (1995). Seismotectonic study in northern Tunisia. Tectonophysics, 209 (1-4), 171-174 (5 pages).

Dlala, M.; Kacem, J., (2007). Carte sismotectonique de la région du grand Tunis au 1/50 000, Ed de l'Office de Topographie et de Cartographie, Tunis. INM publisher. 
Finn, W. D. L., (2001). State of the art for the evaluation of seismic liquefaction potential. Comput. Geotech. J., 29 (5), 329-341 (13 pages).

Hamada, M.; Aydan, Ö., (1992). A report of the site investigation of March 13, 1992 Earthquake of Erzincan, Turkey. ADEP, Association for Development of Earthquake Prediction, 86

Ishihara, K.; Yasuda, S., (1991). Microzonation for Liquefaction Potential during Earthquakes in Japan.

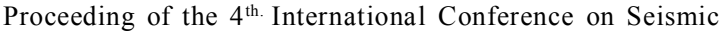
Zonation, 1, 703-724 (22 pages).

Kacem, J., (2004). Etude sismotectonique et évaluation de l'aléa sismique régional du Nord-Est de Tunis: Apport de la sismique réflexion dans l'identification des sources seismogéniques. Thčse de doctorat, Université Tunis, faculté Science Tunis, 200.

Kramer, S. L., (1996). Geotechnical earthquake engineering. New Jersey. Prentice Hall, 348-355.

Ozdemir, A.; Ince, I, (2004). Geology seismotectonics and soil liquefaction susceptibility of Ilgin (west-central part of Turkey) residential area. Eng. Geol., 77 (1-2), 169-188 (20 pages).

Papathanassiou, G.; Pavlides, S.; Ganas, A., (2005). The 2003 earthquake: Field observations and priminary microzonation map based on liquefaction potential index for the town of Lefkada. Eng. Geo.,82, 12-31.

Pecker, A., (1984). Dynamique des sols, Presses de 1'Ecole Nationale des Ponts et des Chaussées, ISBN: 2-85978-330X. 259 .

Philip, H., (1987). Plio-Quaternary evolution of the stress field in Mediterranean zones of subduction and collision. Ann. Geophysic., 5 (2), 301-320 (20 pages).

Pimienta, J., (1959). Le cycle pliocène-actuel dans les bassins paraliques de Tunis, Thèse. Fac. Sci. Paris et Mém. Soc. Géol. Fr., Nelle série XXXVIII, 85, 197.
Rathje, E. M.; Karatas, I.; Stephen, G. W.; Bachhuber, J., (2004). Coastal failures during the 1999 Kocaeli earthquake of Turkey. Soil dyn. Earthquake Eng., 24 (9-10), 699-712 (14 pages).

Rix, G. J; Romero-Hudock, S. (2006). Liquefaction potential mapping in memphis and Shelby County, Tennessee. Engineering Geology, 27.

Sonmez, B.; Ulusay, R., (2008). Liquefaction potential at Izmit Bay: comparison of predicted and observed soil liquefaction during the Kocaeli earthquake. Bull. Eng. Geol. Environ. 67 (1), 1-9 (10 pages).

Soysal, H.; Sipahioglu, S.; Kolçak, D.; ve Altýnok, Y., (1981). Trükiye ve Çevresinin tarihsel deprem katalogu. Tübitak Yayinlari, No: 563 TBAG Seri No: 3486 Sayfa Tübitak Fotog (raf Klis,e Labaratuar ve Ofset Tesisleri Ankara TBAG, 124.

Stephen, F. O.; Scott, M. O.; Russell, A. G., (2004). Field occurrences of liquefaction-induced features: A primer for engineering geologic analysis of paleoseismic shaking. Eng. Geo., 76 (3-4), 209-234 (26 pages).

Ulusay, R.; Aydan, Ö.; Kumsar, H.; Sönmez, H., (2000). Engineering geological characteristic of the 1998 AdanaCeyhan earthquake with particular emphasis on liquefaction phenomena and the role of soil behaviour. Bull. Eng. Geo. Environ., 59 (2), 99-118 (20 pages).

Youd, T. L.; Perkins, D. M., (1978). Mapping liquefactioninduced ground failure potential. J. Geo. Eng. Div., 104 (4), 433-446 (14 pages).

Youd, T. L., (1991). Mapping of earthquake-induced liquefaction for seismic zonation. Procceding of the $4^{\text {th. }}$ international conference on seismic zonation. 1, 111-147 (37 pages).

Yuan, H.; Yang, S. H.; Andrus, R. D.; Juang, H., (2003). Liquefaction induced ground failure: A study of the Chi-Chi earthquake cases. Eng. Geol., 17 (1-2), 141-155 (15 pages).

\section{AUTHOR (S) BIOSKETCHES}

El May, M., Ph.D. research student in the paleoenvironment, Geomaterial and Sismic Risk Laboratory, Departement of Geology, Faculty of Sciences, University Tunis El Manar. Email: elmaymoufida@yahoo.fr

Kacem, J., Lecturer, Departement of Earth Sciences, Faculty of Sciences of Bizerte, Tunisia. Email: jamelkacem@yahoo.fr

Dlala, M., Professor in the paleoenvironment, Geomaterial and Sismic Risk Laboratory, Departement of Geology, Faculty of Sciences, University Tunis Manar. Email: mahmouddlala@yahoo.fr

El May M.; Kacem, J.; Dlala, M., (2009). Liquefaction susceptibility mapping using geotechnical laboratory tests. Int. J. Environ. Sci. Tech., 6 (2), 299-308. 